\title{
Variation of Length of Styloid Process
}

\author{
Variación de Longitud del Proceso Estiloides
}

\begin{abstract}
"Carla Cabral dos Santos Accioly Lins; *Adelmar Afonso de Amorim Júnior; **Bruna Paloma de Oliveira; *"Elma Mariana Verçosa de Melo Silva \& *Raphaela Christianne Maia Soares Torres
\end{abstract}

LINS, C. C. S. A.; JÚNIOR, A. A. A.; OLIVEIRA, B. P.; SILVA, E. M. V. M. \& TORRES, R. C. M. S. Variation of length of styloid process. Int. J. Morphol., 28(4):1277-1280, 2010.

SUMMARY: The styloid process is a bony projection that arises from the tympanic portion of the temporal bone, and its elongation is considered an anomaly that may be related to calcification of the stylohyoid and stylomandibular ligaments, which can trigger a series of symptoms that characterize the Eagle's syndrome. The objective of this study was to report three cases of elongated styloid process seen in human skulls, trying to alert the dentists in the knowledge of this disease in order to include it in their diagnosis, associated with atypical facial pain or in the oral cavity of to facilitate better treatment for these cases.

KEY WORDS: Anatomic variation; Maxillofacial abnormalities; Craniomandibular Disorders.

\section{INTRODUCTION}

The styloid process is a thin and sharp bone structure, protruding downward and forward from the underside of the temporal bone. It is situated between the carotid internal and external, posterior to the pharynx, which cover stylohyoid, styloglossus and stylopharyngeal muscles (Gray, 1977). It has embryonic origin in the Reichert's cartilage of the second arch, together with the stylohyoid ligament and the lesser horn of hyoid bone forms the stylohyoid complex or stylohyoid apparatus (Sá et al., 2004).

The normal length is between 25 and $30 \mathrm{~mm}$, and can vary from person to person and even between the two sides of the same individual. When processes exceed this average it is assigned the term elongation (Pinto et al., 2008).

The elongation of styloid process is considered an anomaly which can be accompanied by calcification of the stylohyoid and stylomandibular ligaments, which can trigger a series of symptoms such as dysphagia, odynophagia, facial pain, ear pain, headache, tinnitus and trismus. This set of symptoms associated with the elongated styloid process is called Eagle's syndrome (Lages et al.,
2006). Several other symptoms are attributed to the syndrome, including: neck pain, foreign body sensation in the throat, pain on rotation of the head, and pain when swallowing (Guimarães et al., 2006, Rosa et al., 2008). However none of these signs and symptoms are pathognomonic for the Eagle's syndrome (Lages et al.).

The analysis of X-rays and patient management, such as digital palpation of the tonsillar fossa, are important tools to confirm the diagnosis of Eagle syndrome.

\section{CASE REPORT}

During routine lessons of the Undergraduate Program of Dentistry, Federal University of Pernambuco, Recife-PE, Brazil, observing human skulls, three cases of elongated styloid process were found. Subsequently, proceeded to the measurement using a caliper with accuracy of $0.05 \mathrm{~mm}$ according Mandarim-de-Lacerda (1999), resulting in a length: 46.50mm (Fig.1 A and B), 41,00mm (right) (Fig. 2 A and B) and 42.55mm (left) (Fig.3 A and B).

\footnotetext{
* Prof. Departamento de Anatomia, Universidade Federal de Pernambuco, Recife-PE, Brazil.

** Curso de Odontologia de la Universidade Federal de Pernambuco, Recife-PE, Brazil.
} 

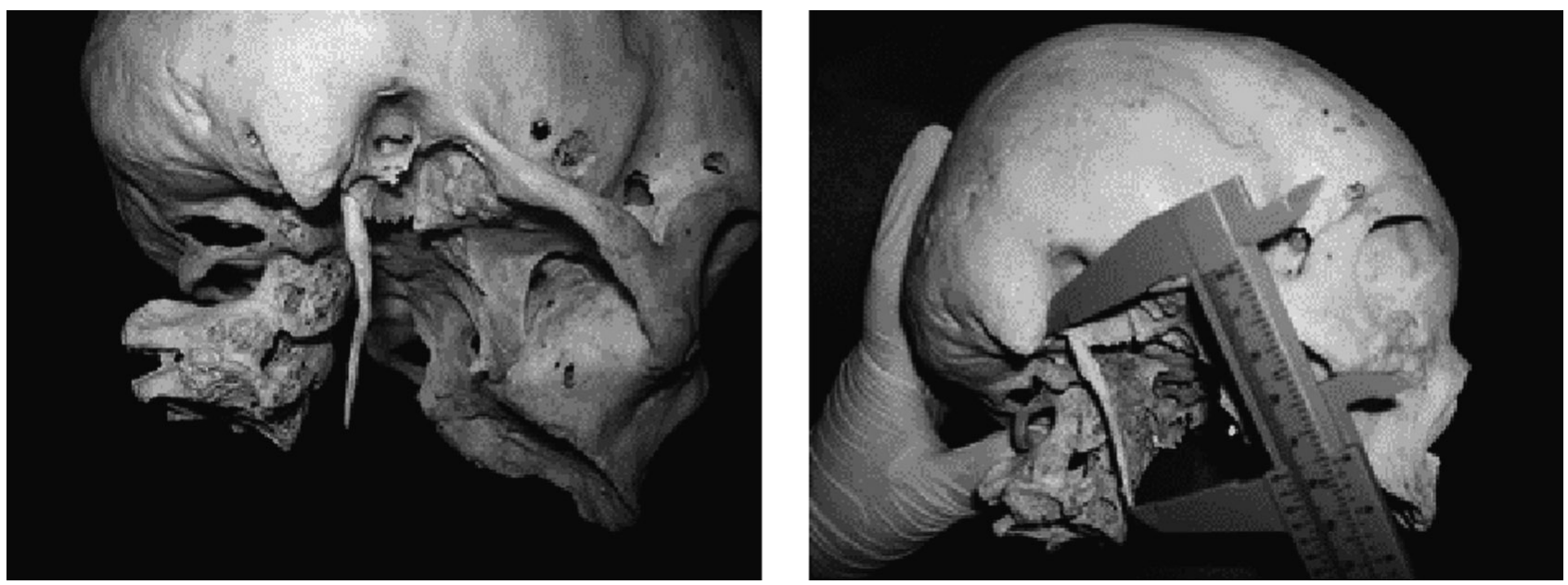

Figs. 1A and B. Lateral view showing the styloid process length $(46.5 \mathrm{~mm})$.
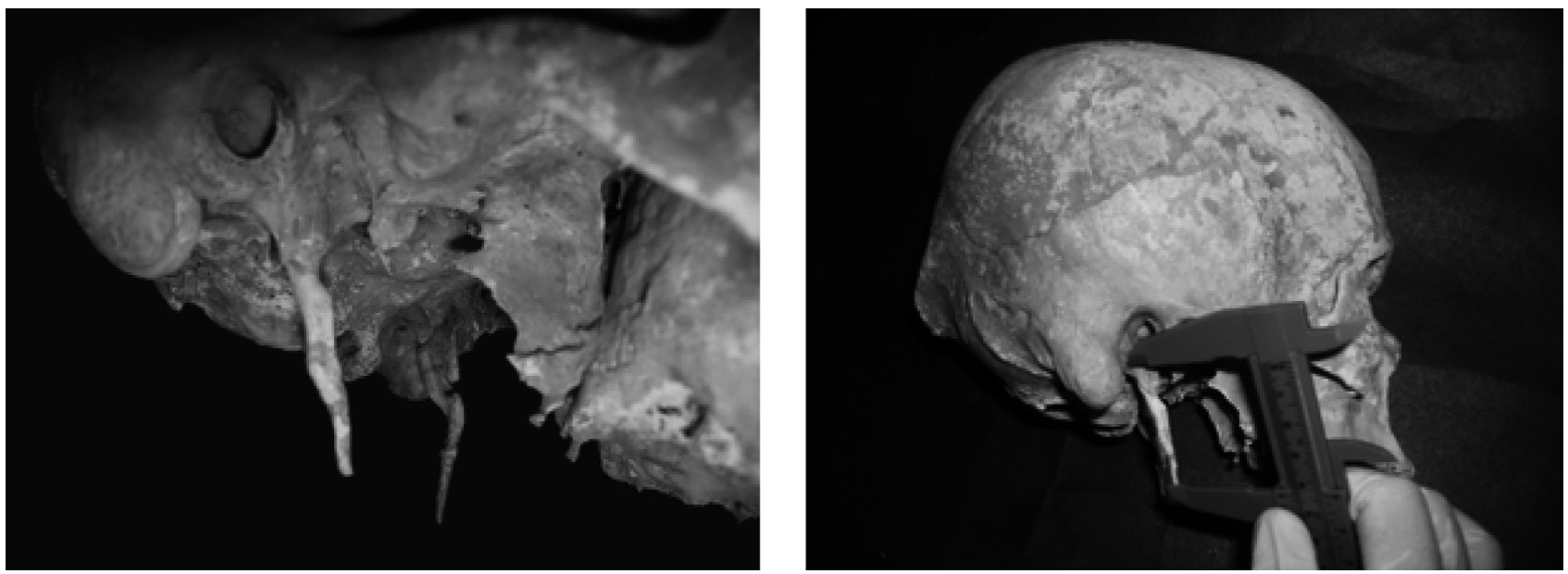

Figs. 2A and B. Lateral view showing the right styloid process length $(41 \mathrm{~mm})$.
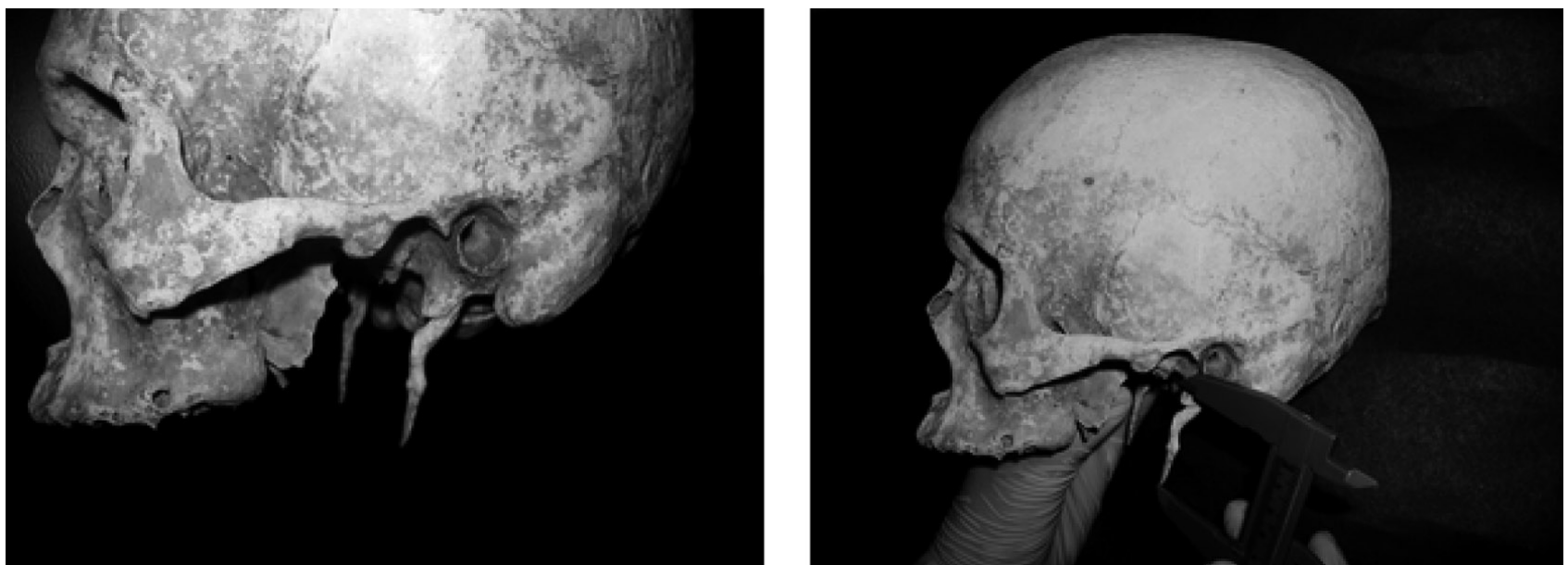

Figs. 3A and B. Lateral view showing the left styloid process length $(42.55 \mathrm{~mm})$. 


\section{DISCUSSION}

The prevalence of elongated styloid process is between $4 \%$ and $28 \%$ of the population (Silva et al., 2002) and in this group, 4 to $10.3 \%$ may develop some symptoms, although there are no data correlating the size of elongation with the severity of symptoms (Murtagh et al., 2001).

There is not a consensus about the etiology of the increase of the styloid process, but several theories as the congenital elongation caused by the persistence of an embryonic cartilaginous leaflet; calcification of stylohyoid ligament resulting in an elongated styloid process, the formation of a bone tissue in the temporal fixation of stylohyoid ligament (Sá et al.) and presence of fibrosis after tonsillectomy (Rovani et al., 2004), are considered as causal factors.

For the diagnosis, an inicial palpation of the tonsillar fossa should be performed the presence of a firm structure in a positive case, is the elongated styloid process. Consistent imaging studies through orthopantomography, lateral jaw radiographs or CT scans will confirm the hypothesis raised in the diagnostic clinical history (Tiago et al., 2002; Maiello \& Alves, 2006; Lages et al.).

The differential diagnosis should include all possible causes of pain in the head and neck, especially trigeminal and glossopharyngeal neuralgia. Other causes include dysfunction of the TMJ, impacted or not erupted third molars (Guzzo et al., 2006), ill-fitting or missing dentures, tumors of the tongue base and hypopharynx, degenerative changes of the cervical spine, chronic tonsillitis and pharyngitis (Rosa et al.).

\section{CONCLUSION}

These reports of the range of increase of size in the styloid process aimed to alert dentists in the knowledge of this disease in order to include it in the differential diagnosis associated with atypical pain in the face or oral cavity in order to facilitate best treatment for these cases.

LINS, C. C. S. A.; JÚNIOR, A. A. A.; OLIVEIRA, B. P.; SILVA, E. M. V. M. \& TORRES, R. C. M. S. Variación del proceso estiloides.Int. J. Morphol., 28(4):1277-1280, 2010.

RESUMEN: El proceso estiloides es una proyección ósea que tiene su origen en la porción timpánica del hueso temporal y su elongación es considerado una anomalía que puede relacionarse con la calcificación de los ligamentos estilohioídeo y estilomandibular, y de esta forma desarrollar una serie de síntomas que caracterizan al Síndrome de Eagle. El objetivo de este trabajo fue describir en tres cráneos humanos la elongación del proceso estiloides y dar a conocer al cirujano dentista esta anomalía, para que la incluya en su diagnóstico, cuando se éste presenta dolores atípicos de la cara o de la cavidad oral, y así facilitar el mejor tratamiento en estos casos.

PALABRAS CLAVE: Variación anatómica; Anomalías maxilofacial; Trastornos Craneomandibulares.

\section{REFERENCES}

Guimarães, S. M. R.; Carvalho, A. C. P. C.; Guimarães, J. P.; Gomes, M. B. G.; Cardoso, M. M. M. \& Reis, H. N. Prevalência de alteração morfológica do processo estilóide em pacientes com desordem temporomandibular. Radiologia Brasileira, 39:407-11, 2006.

Guzzo, F. A. V.; Macedo, J. A. G. C.; Barros, R. S. \& Almeida, D. C. Síndrome de Eagle: Relato de caso. Revista Paraense de Medicina, 20:47-51, 2006.

Gray, H. Anatomy descriptive and applied. London. Longmans, Green and Company, 1977.
Lages, L. P. D.; Monte, T. L.; Freitas, S. A. P.; Falcão, C. A. M. Alongamento do processo estilóide e síndrome de Eagle: considerações anatômicas, clínicas, diagnóstico e prevalência. Odontologia. Clín.-Científ., 5:1838, 2006.

Maiello, V. L. \& Alves, F. E. M. M. Síndrome de Eagle: proposição de critério diagnóstico. Revista da Associação Paulista de Cirurgião-dentista, 60:403-6, 2006.

Mandarim-de-Lacerda, C. A. Métodos quantitativos em morfologia. Eduerj, São Paulo, 1995. 131 pp. 
LINS, C. C. S. A.; JÚNIOR, A. A. A.; OLIVEIRA, B. P.; SILVA, E. M. V. M. \& TORRES, R. C. M. S. Variation of length of styloid process. Int. J. Morphol., 28(4):1277-1280, 2010.

Murtagh, R. D.; Caracciolo, J. T. \& Fernandez, G. CT findings associated with Eagle syndrome. Am. J. Neuroradiol., 22:1401-2, 2001.

Pinto, P.R.O.; Vieira, G. L.; Menezes, L. M.; Rizzatto, S. M. D.; Brücker, M.R.. Avaliação do processo estilóide em sujeitos com discrepância esquelética de Classe III. Rev. Odonto Ciênc., 23:44-47, 2008. Rev. Odonto Ciênc., 23(1):44-7, 2008.

Rosa, R. R.; Kohatsu, L. I.; Moraes, L. C.; Medici Filho, E.; Moraes, M. E. L. \& Castilho, J. C. M. Síndrome de Eagle: revisão da literatura sobre variações, diagnóstico e tratamento. Revista de Odontologia da Universidade Cidade de São Paulo, 20:288-94, 2008.

Rovani, G.; Flores, M. E.; Damian, M. F. \& Conto, F. Prevalência da Síndrome de Eagle na Faculdade de Odontologia da UPF. Revista Médica HSVP, 16:12-4, 2004.

Sá, A. C. D.; Zardo, M.; Paes Júnior, A. J. O.; Souza, R. P.; Barros Neto, F.; Dreweck, M. O.; Oliveira, R.; Neme, M. P.; Rapoport, A. Alongamento do processo estilóide (sindrome de Eagle): relato de dois casos. Radiol. Bras., 37:385-7, 2004.

Silva, H. J.; Moraes, S. R. A. \& Tashiro, T. Análisis morfométrico de los elementos de la cadena estilohioídea. Rev. Chil. Anat., 20:205-10, 2002.

Tiago, R. S. L.; Marques Filho, M. F.; Maia, C. A. S. \& Santos, O. F. S. Síndrome de Eagle: avaliação do tratamento cirúrgico. Rev. Bras. Otorrinolaringol., 68:196-201, 2002.
Correpondence to:

Prof. Carla Cabral dos Santos Accioly Lins Department of Anatomy

Universidade Federal de Pernambuco

Rua manuel de carvalho, $n^{\circ} 310$, apt 303 , aflitos

CEP 52050-370

Recife- PE

BRASIL

Email: cabralcarla1@hotmail.com

Received: 22-06-2010

Accepted: 16-09-2010 